\title{
Pengaruh Inovasi Crowdfunding Terhadap Keputusan Berdonasi
}

\author{
Safira Hasna ${ }^{1}$ dan Irwansyah ${ }^{2}$ \\ ${ }^{1}$ Mahasiswa Pascasarjana Ilmu Komunikasi FISIP Universitas Indonesia \\ ${ }^{2}$ Staf Pengajar Ilmu Komunikasi FISIP Universitas Indonesia \\ Gedung IASTH Lt. 6 Jl. Raya Salemba No. 4 Jakarta 10430, telp. 0217867222 \\ e-mail: ${ }^{1}$ safirahasna2014@gmail.com , ${ }^{2}$ dr.irwansyah.ma@gmail.com
}

\begin{abstract}
Abstrak
Tujuan dari penelitian ini adalah untuk mengetahui adanya pengaruh inovasi crowfunding terhadap keputusan berdonasi pada platform crowdfunding Kitabisa.com. Penelitian menggunakan teori difusi inovasi serta konsep-konsep mengenai crowdfunding, masalah sosial, dan donasi. Penelitian menggunakan paradigma positivis dan pendekatan kuantitatif, dengan melakukan survey kepada donatur Kitabisa.com. Teknik pengambilan sampel yang digunakan adalah purposive sampling, dengan parameter proporsi $P$ yaitu 96 orang yang pernah melakukan donasi di Kitabisa.com melalui kuesioner yang dibagikan secara online (googleform). Data yang didapat dianalisis menggunakan regresi linear untuk melihat seberapa besar pengaruh antar variabel. Hasil penelitian menunjukkan terdapat pengaruh inovasi crowdfunding terhadap keputusan berdonasi sebesar 18,2\%. Inovasi teknologi membuat kemudahan dalam melakukan donasi, namun kampanye pesan juga perlu mendapatkan perhatian khusus untuk membangun kepercayaan sehingga membuat masyarakat melakukan kegiatan donasi.
\end{abstract}

Kata kunci: Crowdfunding, Donasi, Difusi Inovasi, Kitabisa

\begin{abstract}
The objective of this research is to know the influence of crowdfunding innovation on the decision to donate to crowdfunding platforms Kitabisa.com. These are logical frameworks in this research, such as diffusion of innovation theory, crowdfunding, social problems, and donations. This research used the paradigm of positivism and quantitative approach by conducting an online survey from the donor Kitabisa.com. The sample was selected using purposive sampling with parameter $P$ proportions of 96 people who had made a donation at Kitabisa.com. The data were analysed using linear regression to see the influence between variables. The result of the research showed there was an impact of crowdfunding innovation on the decision to donate is $18.2 \%$. Technological innovation makes it easy to make donations, but more attention has to be given to the message campaign which is also essential to build trust so people can make donations.
\end{abstract}

Keywords: Crowdfunding, Donation, Diffusion innovation, Kitabisa

\section{Pendahuluan}

Hadirnya teknologi seperti website, media sosial dan internet, dapat memudahkan segala aktivitas para penggunanya. Salah satu yang hadir saat ini adalah online fundraising, yaitu pendanaan secara online yang biasanya digunakan untuk para wirausaha yang sedang

eISSN: 2477-3255, pISSN: 2086-4884 https://doi.org/10.31849/digitalzone.v10i2. 2719 
mencari pendanaan eksternal. Kegiatan pendanaan yang melibatkan website ini dapat disebut dengan crowdfunding. Pendanaan crowdfunding berbeda dari pembiayaan tradisional usaha baru dalam dua cara penting. Pertama, pendanaan disediakan oleh kontribusi yang relatif kecil dari banyak individu selama batas waktu yang ditentukan (umumnya beberapa minggu). Kedua, donatur dapat melihat berapa banyak yang mendukung proyek tersebut sebelum mengambil keputusan, menunjukkan bahwa keputusan pendaan orang lain memiliki peranan penting dalam suatu keberhasilan proyek crowdfunded [1].

Dalam beberapa tahun terakhir, crowdfunding telah menjadi sumber pendanaan alternatif yang berharga bagi wirausahawan yang mencari pendanaan eksternal. Crowdfunding memungkinkan pengusaha untuk mengumpulkan dana melalui panggilan terbuka di internet. Karakteristik penting adalah adanya manfaat pribadi tambahan yang didanai oleh penyandang dana (yaitu, "crowdfunders") dengan berpartisipasi dalam mekanisme crowdfunding. Manfaat pribadi tambahan ini bervariasi dengan bentuk crowdfunding, mulai dari model berbasis ekuitas, skema bagi hasil, dan pinjaman hingga sumbangan langsung [2].

Ada banyak situs crowdfunding, mulai dari situs besar seperti Kickstarter, Indiegogo, dan Gofundme hingga situs web niche seperti Teespring (t-shirt crowdfunding), DonorChoose (pengumpulan dana amal), dan Patreon (penggalangan dana untuk pembuat konten online). Salah satu platform crowdfunding yang pertama dan terbesar (yang penyumbang dananya bersifat open dari berbagai negara) adalah Kickstarter. Salah satu campaign yang sukses adalah kampanye Pebble Kickstarter, dimana kampanye tersebut sering digunakan untuk menggambarkan kekuatan crowdfunding sebagai sumber pembiayaan bagi pengusaha yang tidak memiliki akses ke sumber lain. Crowdfunding memungkinkan para pendiri untuk mencari pendanaan dengan menarik kontribusi yang relatif kecil dari sejumlah besar orang yang menggunakan internet [3].

Namun, crowdfunding bukan hanya digunakan sebagai pendanaan 'modal', tetapi juga pendanaan sebagai salah satu solusi untuk mengurangi masalah sosial yang ada. Fenomena munculnya platform crowdfunding di Indonesia dimulai pada tahun 2012, dengan munculnya banyak platform yang dapat menjadi sarana bagi masyarakat untuk mewujudkan serta membantu sejumlah proyek sosial. Platform-platform crowdfunding di Indonesia seperti kitabisa, wujudkan, ayopeduli, gandengtangan, dan masih banyak lagi merupakan beberapa contohnya. Salah satu pelopor crowdfunding terbesar di Indonesia adalah kitabisa.com, pada tahun 2018, sebanyak 1juta orang terhubung untuk membantu proyek sosial sejumlah 500 milyar, oleh karena itu peneliti memilih Kitabisa.com sebagai obyek penelitian. Kitabisa.com merupakan platform donasi yang mendukung proyek-proyek sosial yang telah ada sejak tahun 2013. Kitabisa juga memungkinkan proyek lain seperti kategori teknologi, kreativitas, dan bisnis. Situs crowdfunding ini selalu memverifikasi setiap proyek sebelum dipublikasikan. Kitabisa juga memiliki laporan keuangan serta status tentang proyek yang sedang didanai. Sebagai social entreprenurship, Kitabisa mengambil potongan lima persen dari proyek yang didanai [4]. Dalam website Kitabisa.com, pengguna media dapat membaca kisah orang-orang sebelum melakukan donasi, dimana hal tersebut juga menjadi salah satu faktor yang mempengaruhi keinginan orang lain untuk menyumbangkan dana. Media sosial, khususnya twitter juga kerap menjadi salah satu media yang menyebarkan kisah serta ajakan untuk berdonasi, namun situs crowdfunding yang digunakan untuk menggalang dana tetap menggunakan Kitabisa.com.

Untuk mendukung donasi melalui crowdfunding kitabisa.com, dibutuhkan story telling yang kuat sebagai salah satu bentuk kampanye yang mempersuasi orang lain untuk memberikan donasi. Karena, salah satu tantangan dari platform crowdfunding adalah kurangnya pemahaman di dalam organisasi tentang manfaat non-finansial. Crowdfunding terlalu sering dipandang murni sebagai alat penggalangan dana, bukan kombinasi penggalangan dana dan kampanye. 
Akibatnya sering menjadi tanggung jawab tim penggalangan dana, yang menyebabkan organisasi gagal memanfaatkan peluang yang lebih luas dalam crowdfunding [5].

Terdapat beberapa penelitian terdahulu yang berkaitan dengan crowdfunding dan keputusan berdonasi. Degasperi dan Mainaredes (2017) lewat penelitiannya berjudul What motivates money donation? A study on external motivators, menemukan bahwa trust, reward, leadership influences, personal benefit, karakteristik manfaat yang diterima donatur, dan minat di masa depan membuat seseorang ingin melakukan donasi [6]. Penelitian kedua oleh Rakowska (2014) yang berjudul Crowfunding For Inovation, dengan menganalisis serta wawancara 7 proyek crowdfunded yang sukses, seperti memelihara stakeholders dan pengelolaan keuangannya. Temuan dari penelitian ini adalah kesuksesan crowdfunding sangat dipengaruhi oleh peran stakeholders yang mampu mengoptimalkan kampanye untuk dapat menarik perhatian donatur [7]. Penelitian ketiga oleh Kerkhof (2016) berjudul The Influence of a Social Network and Social Interactions On the Success of a Crowdfunding Campaign, menganalisis hubungan media sosial facebook dan interaksi sosial dengan keberhasilan kampanye crowdfunding. Hasil penelitian menunjukkan tidak ada hubungan yang signifikan antara ukuran media sosial dan keberhasilan kampanye, namun interaksi sosial berpengaruh secara signifikan dengan keberhasilan kampanye crowdfunding [8].

Penelitian ini berbeda dengan penelitian-penelitian sebelumnya karena ingin langsung menganalisis pengaruh variabel crowdfunding dengan keputusan berdonasi. Crowdfunding sebagai platform untuk melakukan donasi secara online dapat termasuk kedalam inovasi teknologi yang ada saat ini, untuk memberikan bantuan serta menumbuhkan kesadaran sosial di kalangan masyarakat sehingga membuat masyarakat memiliki keinginan untuk melakukan donasi. Namun, diperlukan kegiatan untuk mengadopsi inovasi teknologi ini guna diterima baik di masyarakat sehingga berdampak keputusan seseorang untuk melalukan donasi. Oleh karena itu, muncul pertanyaan penelitian "Apakah terdapat pengaruh inovasi crowdfunding Kitabisa.com terhadap keputusan berdonasi?", tujuan penelitian ini adalah untuk mengetahui apakah terdapat pengaruh dan jika ada, seberapa besar pengaruh inovasi crowdfunding terhadap keputusan berdonasi, khususnya bagi para donatur Kitabisa.com. Penelitian menggunakan teori difusi inovasi dan metode penelitian survey kepada para donatur kitabisa.com.

\section{Crowdfunding}

Istilah crowdfunding berasal dari konsep besar "crowdsourcing" yang lebih luas, yang melibatkan penggunaan istilah "crowd" untuk mendapatkan ide, umpan balik, dan solusi untuk mengembangkan kegiatan perusahaan. Pendanaan crowdfunding selalu terbuka, melalui internet, dalam bentuk donasi, biasanya terdapat imbalan kepada yang mendukung untuk suatu tujuan tertentu [9].

Terdapat tiga aktor utama yang terlibat dalam crowdfunding, yaitu penggagas proyek, pendukung (yang menyumbangkan dana), serta platform yang memoderasi. Melalui platform moderasi, para penggagas proyek membuka diri terhadap masukan atau kontribusi dari para pendukungnya (misalnya, storytelling, update proyek yang dijalankan) yang mendukung gagasan / proyek tersebut dengan berbagai cara [10].

Umumnya, tujuan crowdfunding adalah untuk mengumpulkan modal dalam jumlah kecil, misalnya dibawah $\$ 1000$, atau untuk memulai proyek sekali tertentu. Namun, semakin banyak crowdfunding yang menjadi satu-satunya modal benih usaha yang memungkinkan pengusaha untuk mengumpulkan dana awal untuk memulai usaha baru mereka. Dengan demikian, pendanaan crowdfunding dapat digunakan untuk mendanai berbagai pendiri tradisional dan non-tradisional. Namun, pendanaan tidak harus menjadi satu-satunya tujuan upaya crowdfunding, bahkan dalam konteks kewirausahaan. Sebagai contoh tujuan lain, 
crowdfunding telah digunakan oleh para pendirinya untuk menunjukkan permintaan akan produk yang diusulkan, yang dapat mengarah pada pendanaan dari sumber yang lebih tradisional. Crowdfunding juga telah digunakan untuk tujuan pemasaran, menciptakan minat pada proyek-proyek baru pada tahap awal pengembangan [11].

Pengumpulan modal usaha bukan satu-satunya menjadi tujuan suatu proyek crowdfunding. Manfaat pribadi tambahan crowdfunding bervariasi dengan bentuk crowdfunding, mulai dari model berbasis ekuitas, skema bagi hasil, dan pinjaman hingga sumbangan langsung (donasi) [9]. Crowdfunding sebagai platform penggalangan dana amal / sumbangan langsung (donasi) seperti Kitabisa.com dapat membuat kemudahan bagi masyarakat untuk berbagi. Siapapun bisa menggalang dana dengan memasukkan konten, cerita, yang setelahnya akan di verifikasi oleh pihak Kitabisa.com. Lewat platform crowdfunding, baik penggalang dana ataupun orang lain bisa menyebarkan cerita ke jejaring sosial lainnya sehingga penggalangan dana dapat berhasil sesuai dengan target yang diinginkan. Penyumbang dana juga dapat menggunakan nama asli atau anonim dalam melakukan sumbangan dana. Setelahnya, para penyumbang dana dapat menghubungi langsung pihak penggalang dana untuk mendapatkan update terkait dengan proyek / penggalangan dana tersebut.

\section{Keputusan Donasi}

Masyarakat pasti terus menghadapi masalah yang kompleks. Masalah yang ada hari ini dan keadaan serta bagaimana mengatasinya, pasti berbeda dengan beberapa dekade yang lalu. Dalam suatu negara, pasti akan ada masalah sosial, salah satu contoh masalah sosial yang dihadapi di Indonesia khususnya, adalah seputar kesehatan, ekonomi, dan pendidikan. Apa yang dianggap dan tidak dianggap sebagai masalah sosial dapat sangat bervariasi dari waktu ke waktu. Masalah sosial dapat diartikan sebagai masalah yang menyangkut hal umum bagi semua masyarakat, dan adanya upaya tertentu untuk menghadapi situasi soial tersebut. Contoh, adanya upaya pemerintah dalam menurunkan angka kematian, penurunan pengangguran, tunawisma, turunnya angka gizi buruk, dan lain sebagainya. Dengan adanya masalah sosial yang terus ada, menjadikan seseorang dapat melakukan keputusan untuk melakukan kegiatan amal atau berdonasi untuk membantu serta mengurangi permasalahan yang ada. Untuk dapat membuat seseorang melakukan donasi, diperlukan kinerja yang baik dari organisasi amal, ataupun adanya penyempurnaan teknik penggalangan dana yang diperlukan untuk mendapatkan donatur potensial.

\section{Operasionalisasi Konsep}

Tabel 1. Operasionalisasi Konsep Variabel X (Inovasi Crowdfunding)

\begin{tabular}{|c|c|c|c|}
\hline Variabel & Dimensi & Indikator & Skala Data \\
\hline $\begin{array}{l}\text { Inovasi } \\
\text { Crowdfunding }\end{array}$ & Knowledge & \begin{tabular}{llr} 
- & Mengetahui & kitabisa.com \\
merupakan inovasi & crowdfunding \\
& di Indonesia & \\
- & Mengetahui & kitabisa.com \\
merupakan & \multicolumn{2}{c}{ platform } \\
& crowdfunding terbesar di \\
& Indonesia \\
- & Mengetahui bahwa kitabisa.com \\
& dapat diakses melalui smartphone \\
- & Mengetahui bahwa kitabisa.com \\
& memiliki sistem pembayaran \\
& yang mudah dilakukan
\end{tabular} & Interval \\
\hline
\end{tabular}




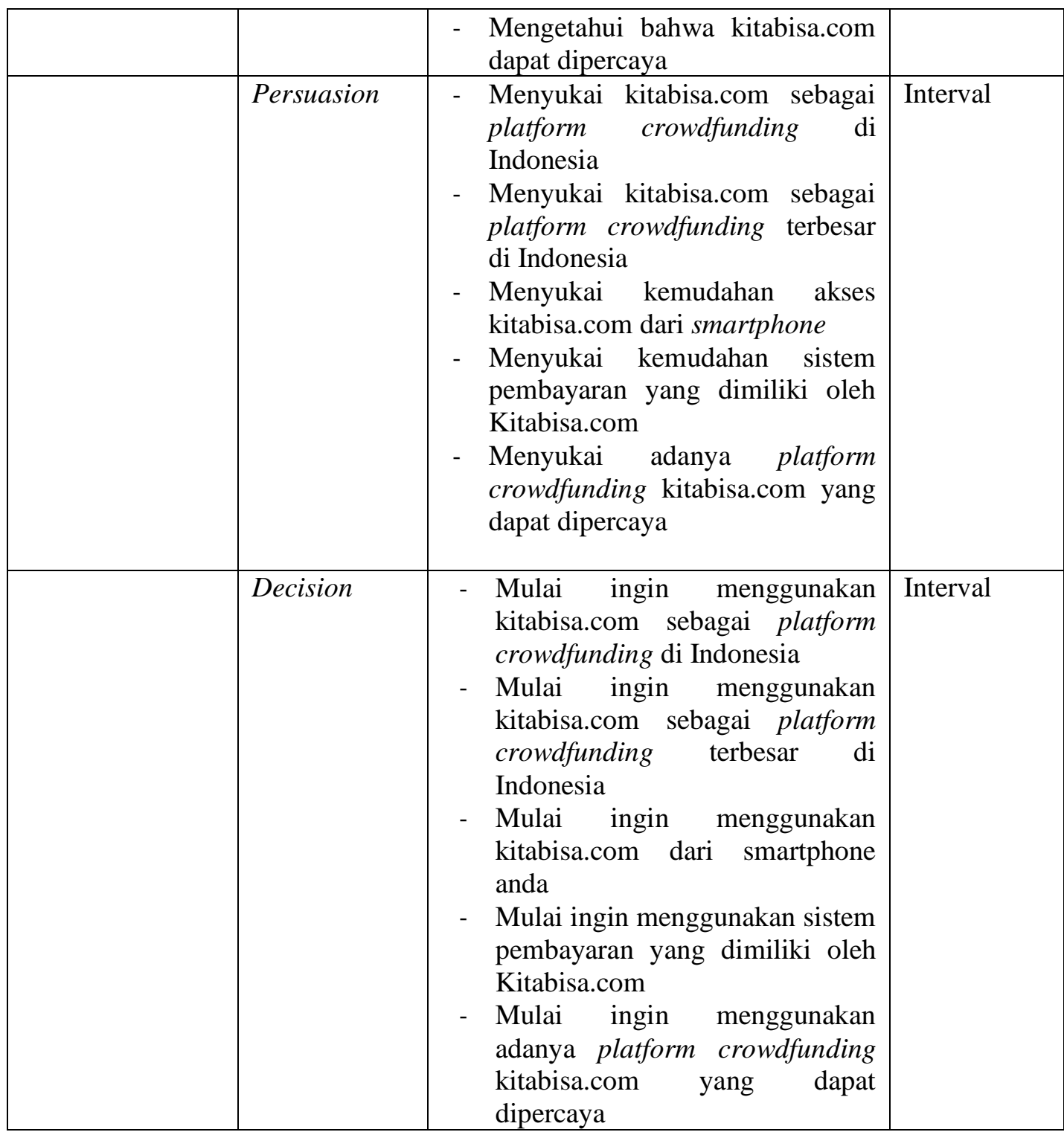

Tabel 2. Operasionalisasi Konsep Variabel Y (Keputusan Berdonasi)

\begin{tabular}{|c|c|c|c|}
\hline Variabel & Dimensi & Indikator & Skala Data \\
\hline $\begin{array}{l}\text { Keputusan } \\
\text { Berdinasi }\end{array}$ & $\begin{array}{l}\text { Need } \\
\text { Recognition }\end{array}$ & $\begin{array}{llr}\text { - } & \text { Sadar } & \text { banyaknya } \\
\text { permasalahan } & \text { sosial di } \\
& \text { Indonesia } \\
\text { - } & \text { Sadar donasi } \\
\text { merupakan salah satu } \\
\text { upaya } \\
\text { menyelesaikan } \\
\text { permasalahan sosial di } \\
\text { Indonesia } \\
\text { - } & \text { Sadar akan kemudahan }\end{array}$ & Interval \\
\hline
\end{tabular}

eISSN: 2477-3255, pISSN: 2086-4884

https://doi.org/10.31849/digitalzone.v10i2. 2719 


\begin{tabular}{|c|c|c|c|}
\hline & & $\begin{array}{l}\text { internet yang mampu } \\
\text { membuat donasi lebih } \\
\text { mudah } \\
\text { - Sadar akan kebutuhan } \\
\text { transaksi dalam donasi } \\
\text { yang cepat } \\
\text { - Sadar akan kebutuhan } \\
\text { untuk berdonasi yang } \\
\text { mudah dari keluarga } \\
\text { - Sadar akan kebutuhan } \\
\text { untuk berdonasi yang } \\
\text { mudah dari teman } \\
\text { Sadar akan kebutuhan } \\
\text { untuk berdonasi yang } \\
\text { mudah dari media cetak } \\
\text { Sadar akan kebutuhan } \\
\text { untuk berdonasi yang } \\
\text { mudah dari media } \\
\text { sosial }\end{array}$ & \\
\hline & $\begin{array}{l}\text { Information } \\
\text { Search }\end{array}$ & 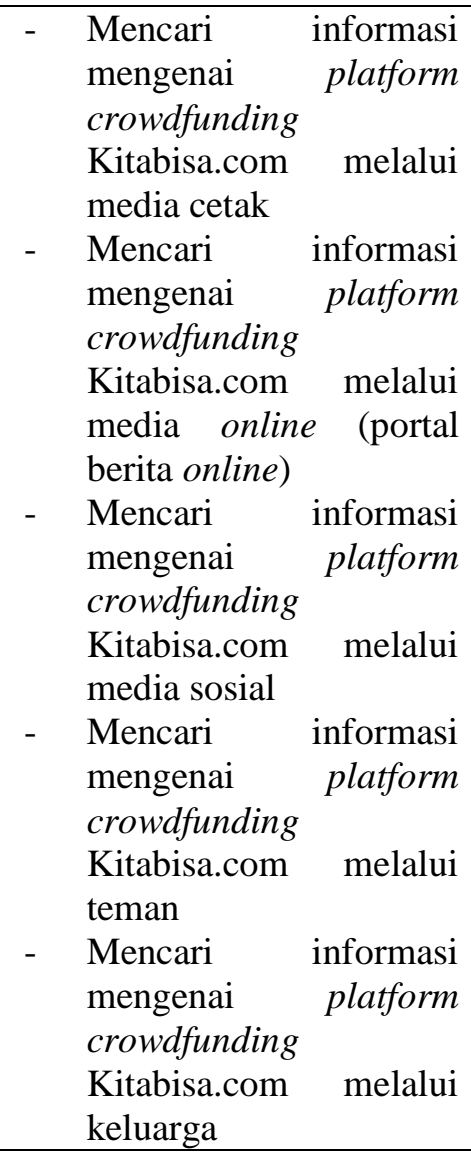 & Interval \\
\hline & $\begin{array}{l}\text { Evaluation of } \\
\text { Alternative }\end{array}$ & $\begin{array}{llr}\text { - } & \text { Mempertimbangkan } \\
\text { informasi mengenai } & \text { metform crowdfunding }\end{array}$ & Interval \\
\hline
\end{tabular}




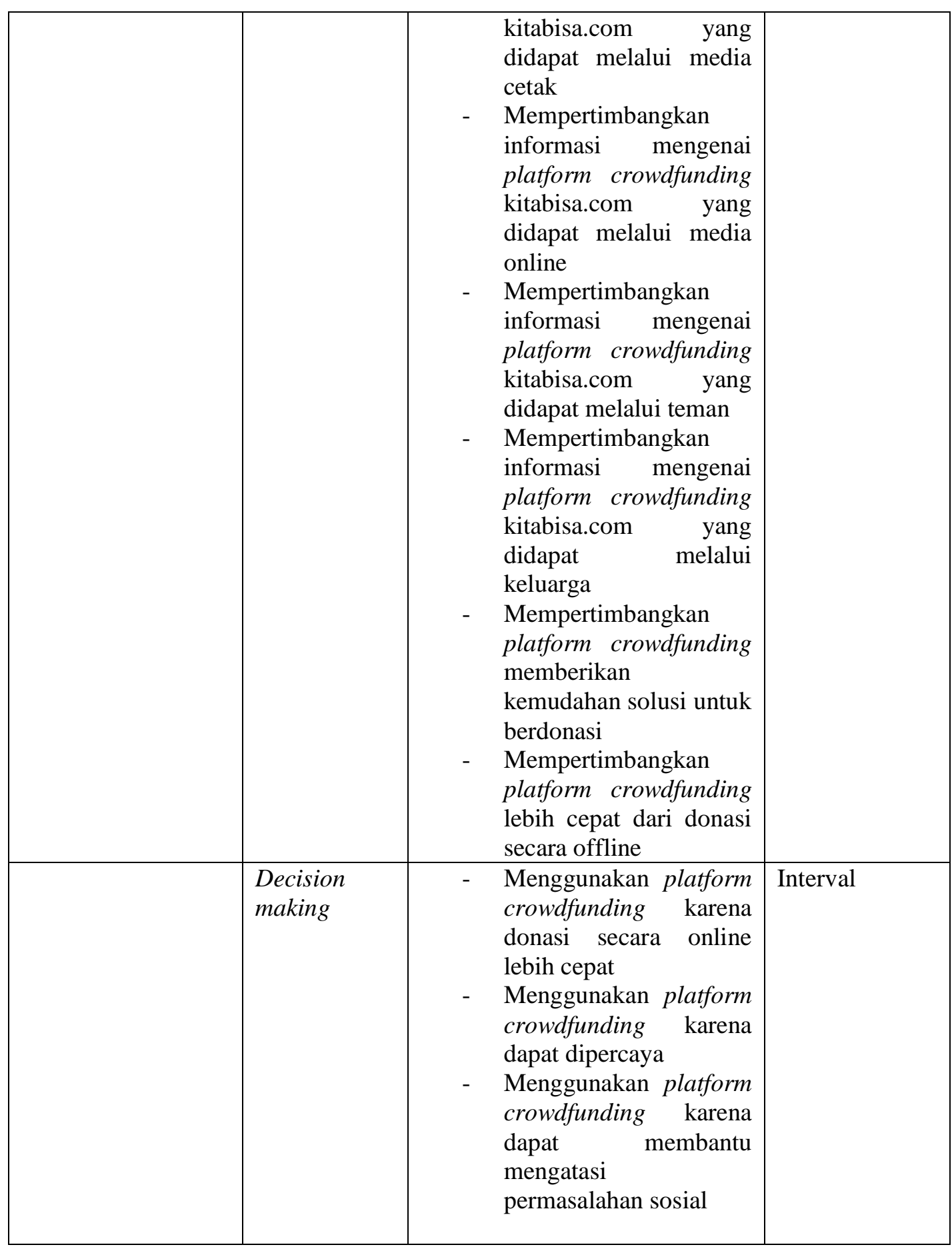

\section{Metode Penelitian}

Metode penelitian yang digunakan adalah kuantitatif dimana penelitian kuantitatif menguji suatu teori dengan menentukan hipotesis dan pengumpulan data untuk mendukung suatu hipotesis yang telah ditentukan [12]. Metode kuantitatif dapat menggunakan desain eksperimen (untuk menilai sikap sebelum dan sesudah eksperimen), survey, dan analisis isi.

eISSN: 2477-3255, pISSN: 2086-4884 https://doi.org/10.31849/digitalzone.v10i2. 2719 
Data yang dikumpulkan kemudian dianalisis dengan menggunakan prosedur statistik dan pengujian hipotesis.

Peneliti dalam penelitian kuantitatif perlu melakukan pengukuran untuk menguji hipotesis, mengevaluasi penjelasan, memberikan dukungan empiris terhadap teori, atau mempelajari masalah terapan. Pada proses pengukuran data kuantitatif, peneliti berpikir dan membuat keputusan mengenai pengukuran dalam penelitian sebelum mengumpulkan data, dan data dalam format standar yang seragam yaitu angka. Terdapat dua proses utama dalam pengukuran; konseptualisasi dan operasionalisasi. Pertama, peneliti mengkonseptualisasikan variabel, memberikan definisi konseptual yang jelas; berikutnya peneliti dapat mengoperasionalkan dengan mengembangkan definisi operasional atau seperangkat indikator untuk itu; dan terakhir, menerapkan indikator untuk mengumpulkan data dan menguji hipotesis empiris.

Populasi dalam penelitian ini adalah 1) pria dan wanita, 2) pengguna media sosial, 3) pernah melakukan kegiatan donasi di platform Kitabisa.com. Peneliti tidak mungkin meneliti seluruh populasi yang ada, oleh karena itu dibutuhkan sampel yang merupakan bagian populasi untuk diteliti. Penelitian ini menggunakan teknik non-probability sampling, dengan cara ini semua elemen populasi belum tentu memiliki peluang yang sama untuk dipilih menjadi anggota sampel karena ada bagian tertentu yang secara sengaja tidak dimasukkan dalam pemilihan untuk mewakili populasi. Pengambilan sampel secara non acak pada penelitian ini yaitu purposive sampling. Dalam hal ni pemilihan sampel berdasarkan pada karakteristik tertentu yang dianggap mempunyai sangkut paut dengan karakteristik populasi yang sudah diketahui sebelumnya.

Karena jumlah populasi tidak diketahui maka pengambilan sampel dilakukan dengan menggunakan rumus sebagai berikut:

$$
n \geq p \cdot q \cdot\left(\frac{Z_{a / 2}}{E}\right)^{2}
$$

Dimana

$\mathrm{N}$ : ukuran sampel

$\mathrm{n}$ : ukuran sampel

p: perkiraan proporsi pada populasi. Jika $\mathrm{p}$ tidak diketahui maka $\mathrm{p}$ diambil $=0,5$

$\mathrm{q}: 1-\mathrm{p}$

$Z_{a / 2}$ : Nilai standar daftar luar normal standar, dimana tingkat kepercayaan $a=95 \%, Z_{a / 2}=$ $\mathrm{Z}_{0,05 / 2}=\mathrm{Z}_{0,025}=1,96$ (didapat dari Tabel Z Distribusi Normal)

E: Estimasi kesalahan, yaitu 10\% / 0,1

$$
\begin{gathered}
n \geq p \cdot q \cdot\left(\frac{Z_{a / 2}}{E}\right)^{2} \\
n \geq 0,5 \cdot 0,5 \cdot\left(\frac{1,96}{0,1}\right)^{2} \\
n \geq 0,25 \cdot 384,16 \\
n \geq 96,04 \\
n \geq 96
\end{gathered}
$$

Maka akan diambil sampel minimal 96 orang.

Peneliti melakukan survey dengan menyebarkan kuesioner melalui aplikasi google form (online kuesioner). Selanjutnya, data yang diperoleh lewat survery dianalisis dengan menggunakan metode statistik dengan bantuan software Statictical Package for Social Science (SPSS) versi 20 untuk mempercepat hitungan.

Berikut model analisis yang dapat digambarkan dalam penelitian. 
Bagan 1. Model Analisis Antara Variabel

Inovasi Crowdfunding

(Variabel X)

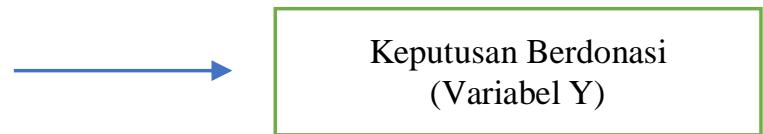

Pada penelitian ini,inovasi crowdfunding bertindak sebagai variable $\mathrm{X}$ atau variabel independen dan keputusan berdonasi sebagai variabel $\mathrm{Y}$ atau variabel dependen.

Adapun hipotesis penelitian (Ha) yaitu: terdapat pengaruh inovasi crowdfunding terhadap keputusan berdonasi.

\section{Hasil dan Pembahasan}

Pada penelitian ini, penyebaran kuesioner dengan menggunakan google form, yaitu layanan form secara online dari aplikasi yang disediakan Google. Kuesioner dibuat dalam link dan disebarkan lewat media sosial instagram, whatsapp, dan line sehingga menghasilkan data dan mendapatkan seluruh tanggapan dari responden. Untuk mengukur validitas, butir instrumen dinyatakan valid jika $\mathrm{r}$ hitung $>\mathrm{r}$ tabel, dimana untuk uji kuesioner sebanyak 96 orang responden nilai $\mathrm{df}=\mathrm{n}-2, \mathrm{df}=96-2=94 \mathrm{r}$ tabelnya sebesar 0,2006. Dan untuk melihat reliabel atau tidaknya suatu instrumen, alpha croanbach harus lebih dari 0,6.

Uji reliabilitas pada variabel inovasi crowdfunding dan keputusan donasi dilakukan secara keseluruhan indikator kepada 96 responden yang terdiri dari 15 item pertanyaan dan 22 pertanyaan yang dianalisa menggunakan SPSS versi 20 dan dapat dikatakan reliabel jika alpha croanbachnya $>0,6$. Hasil uji reliabilitas inovasi crowdfunding dan keputusan berdonasi dapat dilihat di tabel berikut.

Tabel 3. Uji Reliabilitas Inovasi Crowdfunding

Reliability Statistics

\begin{tabular}{|r|r|}
\hline \multicolumn{1}{|c|}{$\begin{array}{c}\text { Cronbach's } \\
\text { Alpha }\end{array}$} & N of Items \\
\hline 922 & 15 \\
\hline
\end{tabular}

Tabel 4. Uji Reliabilitas Keputusan Berdonasi

Reliability Statistics

\begin{tabular}{|r|r|}
\hline $\begin{array}{r}\text { Cronbach's } \\
\text { Alpha }\end{array}$ & N of Items \\
\hline, 885 & 22 \\
\hline
\end{tabular}

Penelitian ini menggunakan sampel sebanyak 96 responden dari donatur Kitabisa.com, sebagai awal proses analisis dalam penelitian ini dilakukan analisis terhadap karakteristik responden yang dikelompokkan berdasarkan usia, jenis kelamin, pekerjaan, serta pengetahuan tentang Kitabisa.com.

Gambar 1. Karakteristik Responden Berdasarkan Usia

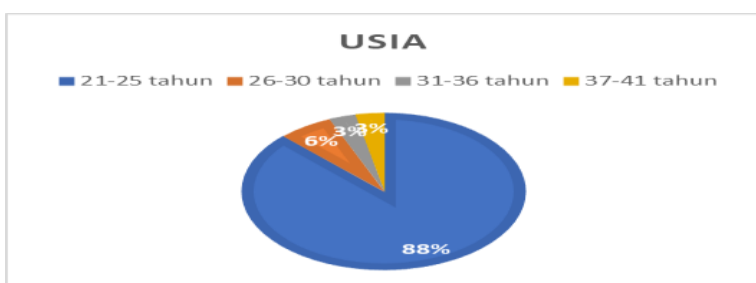

eISSN: 2477-3255, pISSN: 2086-4884

https://doi.org/10.31849/digitalzone.v10i2. 2719 
Gambar 2. Karakteristik Responden Berdasarkan Jenis Kelamin

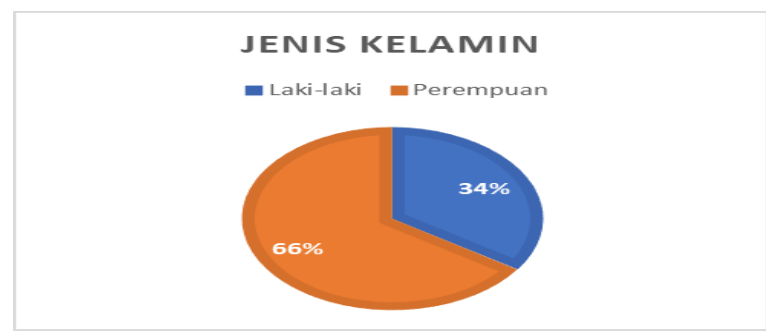

Gambar 3. Karakteristik Responden Berdasarkan Pekerjaan

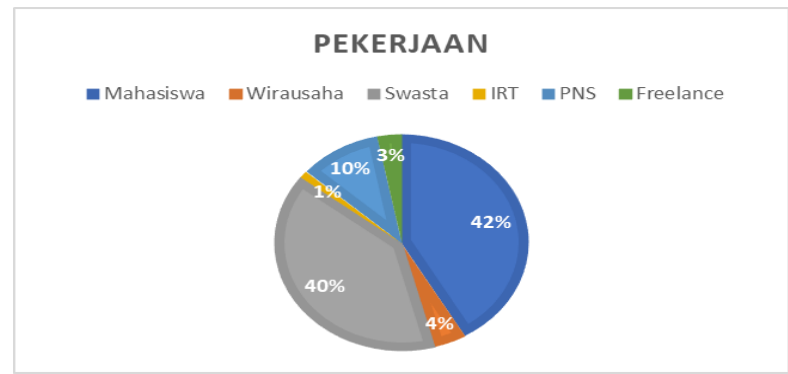

Peneliti menggunakan uji regresi linear untuk mengetahui seberapa besar pengaruh inovasi crowfunding terhadap keputusan berdonasi.

Tabel 5. R square Antara Variabel Inovasi Crowdfunding Terhadap Keputusan Berdonasi

Model Summary

\begin{tabular}{|l|r|r|r|r|}
\hline Model & \multicolumn{1}{|c|}{$\mathrm{R}$} & $\mathrm{R}$ Square & $\begin{array}{c}\text { Adjusted R } \\
\text { Square }\end{array}$ & $\begin{array}{c}\text { Std. Error of } \\
\text { the Estimate }\end{array}$ \\
\hline 1 &, $426^{\mathrm{a}}$ &, 182 &, 173 & 8,140 \\
\hline
\end{tabular}

a. Predictors: (Constant), Inovasi_Crowdfunding

Dari tabel diatas, didapatkan variabel inovasi crowdfunding mempengaruhi variabel keputusan berdonasi dengan nilai $\mathrm{R}$ square sebesar 0,182 atau $18,2 \%$ dimana sisa nilai tersebut yaitu sebesar $81,8 \%$ merupakan faktor lain yang mempengaruhi keputusan dalam melakukan donasi.

Tabel 6. Uji Anova Antara Variabel Inovasi Crowdfunding Terhadap Keputusan Berdonasi

\begin{tabular}{|c|c|c|c|c|c|c|}
\hline \multicolumn{7}{|c|}{ ANOVA $^{a}$} \\
\hline & & $\begin{array}{c}\text { Sum of } \\
\text { Squares }\end{array}$ & $\mathrm{df}$ & Mean Square & $\bar{F}$ & Sig. \\
\hline \multirow{3}{*}{1} & Regression & 1382,394 & 1 & 1382,394 & 20,864 &, $000^{\mathrm{b}}$ \\
\hline & Residual & 6228,095 & 94 & 66,256 & & \\
\hline & Total & 7610,490 & 95 & & & \\
\hline
\end{tabular}

a. Dependent Variable: Keputusan_Berdonasi

b. Predictors: (Constant), Inovasi_Crowdfunding 
Tabel 7. Uji T Pengaruh Variabel Inovasi Crowdfunding Terhadap Keputusan Berdonasi Coefficients $^{\mathbf{a}}$

\begin{tabular}{|c|c|c|c|c|c|}
\hline \multirow[t]{2}{*}{ Model } & \multicolumn{2}{|c|}{$\begin{array}{l}\text { Unstandardized } \\
\text { Coefficients }\end{array}$} & $\begin{array}{l}\text { Standardized } \\
\text { Coefficients } \\
\end{array}$ & \multirow[t]{2}{*}{$\mathrm{t}$} & \multirow[t]{2}{*}{$\overline{\text { Sig. }}$} \\
\hline & B & Std. Error & Beta & & \\
\hline (Constant) & 40,231 & 6,337 & & 6,349 &, 000 \\
\hline $\begin{array}{ll}\text { Inovasi_Crowdfun } \\
\text { ding }\end{array}$ & ,567 & , 124 & ,426 & 4,568 & , 000 \\
\hline
\end{tabular}

a. Dependent Variable: Keputusan_Berdonasi

Dari tabel di atas, diketahui nilai thitung > t tabel, yaitu 4,568 > 1,66055 dan sig 0,000 $<0,05$ yang artinya Ha diterima. Artinya, koefisien regresi signifikan dan variable $\mathrm{X}$ (inovasi crowdfunding) berpengaruh secara signifikan terhadap variable Y (keputusan berdonasi).

Dari hasil uji statistik, terdapat pengaruh inovasi crowdfunding terhadap keputusan berdonasi, tetapi besar pengaruh yang ada sangat lemah yaitu hanya sebesar 18,2\%. Hal ini dikarenakan masih banyak faktor-faktor lainnya yang dapat membuat seseorang untuk melakukan donasi. Kebanyakan responden menganggap inovasi crowdfunding merupakan salah satu inovasi yang dapat mengatasi permasalahan sosial di Indonesia (pendidikan, kesehatan, dan lain sebagainya). Namun, tidak dipungkiri inovasi crowdfunding ini masih terasa asing, hal ini dilihat masih banyaknya responden yang menjawab butir pertanyaan mengetahui Kitabisa.com sebagai platform crowdfunding terbesar di Indonesia serta menggunakan crowdfunding karena dapat dipercaya dengan jawaban tidak setuju. Kembali pada konsep crowdfunding, salah satu tantangan yang dihadapi oleh adanya inovasi ini adalah masih dinilai murni sebagai alat penggalangan dana tanpa melihat kampanye atau pesan yang ada di dalamnya. Dengan sedikitnya angka pengaruh antara variabel, peneliti menarik gagasan bahwa proses difusi melibatkan proses waktu yang tidak sebentar, dimana seorang individu dapat beralih dari pengetahuan pertama tentang mengadopsi suatu inovasi. Peneliti melihat kebanyakan responden masih mengandalkan donasi secara offline, namun karena ada proses pembayaran yang mudah (transfer, gopay, dan uang elektronik lainnya), mereka memilih untuk mencoba menggunakan platform crowdfunding. Dalam proses pencarian informasi terkait dengan crowdfunding yang dipakai sebelum melakukan donasi, pencarian informasi oleh responden masih dirasa kurang karena jawaban mayoritas hanya mencari informasi melalui media sosial, padahal teman dan keluarga juga dapat memberikan pendapat secara langsung yang dapat menjadi referensi dalam melakukan donasi di platform crowdfunding.

Penelitian terdahulu terkait crowdfunding kebanyakan meneliti inovasi crowdfunding sebagai variabel dependen dimana $\mathrm{H} 2$ diterima yaitu adanya hubungan yang signifikan antara media sosial dan keberhasilan kampanye dapat memberikan pengaruh yang besar terhadap keberhasilan crowdfunding dengan besar $\mathrm{R}$ square sebesar 0,302 atau 30,2\%, berbeda dengan penelitian ini yang menjadikan inovasi crowdfunding sebagai variabel independen. Karena banyaknya faktor lain yang mempengaruhi keputusan berdonasi bagi responden, peneliti beranggapan bahwa inovasi crowdfunding harus di mediasi oleh beberapa variabel lainnya untuk dapat memberikan pengaruh yang kuat kepada masyarakat untuk melakukan donasi, misalnya pesan atau kampanye yang ada dalam crowdfunding, selebriti atau brand ambassador untuk memperkenalkan manfaat crowdfunding sebagai inovasi teknologi untuk donasi yang mampu mengatasi permasalahan sosial. Oleh karena itu, penting bagi pihak penyedia crowdfunding maupun penggalang dana untuk melakukan persiapan kampanye terkait inovasi teknologi ini. 


\section{Kesimpulan}

Hasil Pengujian menunjukkan, terdapat pengaruh inovasi crowdfunding Kitabisa.com terhadap keputusan berdonasi dengan nilai sig $=0,000<0,05$, yang artinya Ha diterima. Inovasi crowdfunding berpengaruh terhadap keputusan berdonasi dengan presentase 18,2\%, artinya $81,8 \%$ dipengaruhi faktor lain yang tidak dijelaskan dalam penelitian. Dengan adanya inovasi teknologi, akan membuat semakin mudah dan cepatnya melakukan aktivitas salah satunya untuk keperluan melakukan donasi. Namun, platform crowdfunding untuk keperluan charity bukan sekedar platform penggalangan dana dimana kampanye pesan perlu mendapatkan perhatian khusus untuk membangun kepercayaan dan membuat masyarakat melakukan kegiatan donasi.

Berdasarkan penelitian yang dilakukan, secara teoritis penelitian dapat merekomendasikan adanya pengembangan mengenai konsep inovasi crowdfunding sebagai salah satu faktor seseorang untuk melakukan keputusan berdonasi, secara praktis penelitian dapat menjadi pertimbangan pihak crowdfunding untuk memperhatikan bagaimana pesan harus dibangun dapat dipercaya oleh masyarakat agar mempengaruhi keputusan dalam melakukan donasi. Penelitian memiliki beberapa keterbatasan seperti tidak meneliti tingkat perbedaan pengaruh platform crowdfunding satu dengan lainnya, serta tidak meneliti variabel lain sebagai mediator yang memberikan pengaruh tidak langsung terhadap keputusan berdonasi. Karena besar pengaruh inovasi crowdfunding lemah, maka perlu diteliti lagi faktor lainnya yang dapat mempengaruhi keputusan berdonasi, selain itu perlu diteliti lebih lanjut bagaimana perbandingan penggunaan crowdfunding dan offline fundraising dalam mempengaruhi seseorang untuk melakukan kegiatan donasi.

\section{Daftar Pustaka}

[1] B. L. Bayus and V. Kuppuswamy, "Crowdfunding creative ideas: the dynamics of project backers in Kickstarter," SSRN Electron. J., p. 34, 2014.

[2] T. Kim, M. H. Por, and S. B. Yang, "Winning the crowd in online fundraising platforms: The roles of founder and project features," Electron. Commer. Res. Appl., vol. 25, pp. 86-94, 2017.

[3] T. E. Brown, E. Boon, and L. F. Pitt, "Seeking funding in order to sell: Crowdfunding as a marketing tool," Bus. Horiz., vol. 60, no. 2, pp. 189-195, 2017.

[4] N. Freischlad, "Five crowdfunding sites in Indonesia," 2015. [Online]. Available: https://www.techinasia.com/crowdfunding-future-indonesia-crowdfunding-sites. [Accessed: 18-May-2019].

[5] J. Bone and P. Baeck, crowdfunding good causes. London: Nesta, 2016.

[6] N. C. Degasperi and E. W. Mainardes, "What motivates money donation? A study on external motivators," Rev. Adm., vol. 52, no. 4, pp. 363-373, 2017.

[7] J. Bakker-Rakowska, "Crowdfunding for Innovation: A Qualitative Research on Resources, Capabilities and Stakes," master thesis master Sci. Bus. Adm. Program., 2014.

[8] A. J. Kerkhof, "The influence of a social network and social interactions on the success of a crowdfunding campaign," 7th IBA Bachelor Thesis Conf., 2016.

[9] P. Belleflamme, T. Lambert, and A. Schwienbacher, "Crowdfunding: Tapping the right crowd," J. Bus. Ventur., vol. 29, no. 5, pp. 585-609, 2014.

[10] C. C. Chu, Y. F. Cheng, F. S. Tsai, S. B. Tsai, and K. H. Lu, "Open innovation in crowdfunding context: Diversity, knowledge, and networks," Sustain., vol. 11, no. 1, pp. $1-11,2019$.

[11] E. Mollick, "The dynamics of crowdfunding: An exploratory study," J. Bus. Ventur., vol. 29, no. 1, pp. 1-16, 2014. 
[12] J. W. Creswell, Research Design: Qualitative, Quantitative, and Mixed Methods Approaches, 4th Editio. California: Sage Publications, 2014.

\section{(c) (i) (2)}

BY SA Digital Zone: Jurnal Teknologi Informasi dan Komunikasi is licensed under a Creative Commons Attribution International (CC BY-SA 4.0) 